Saudi Journal of Medicine

Abbreviated Key Title: Saudi J Med ISSN 2518-3389 (Print) |ISSN 2518-3397 (Online) Scholars Middle East Publishers, Dubai, United Arab Emirates Journal homepage: https://saudijournals.com/sjm

Original Research Article

\title{
Obesity and Thyroid Dysfunction
}

\section{Marhari $\mathrm{H}^{1^{*}}$, Houari $\mathrm{H}^{1}$, Salhi $\mathrm{H}^{1,2,3}$, El Ouahabi $\mathrm{H}^{1,2,3}$}

${ }^{1}$ Department of Endocrinology, Diabetology and Nutrition, University Hospital Hassan II, Fez, Morocco

${ }^{2}$ University Sidi Mohamed Ben Abdellah; Faculty of Medicine and Pharmacy, Fez, Morocco

${ }^{3}$ Epidemiology and Research in Health Sciences

DOI: $10.36348 / \mathrm{sjm} .2020 . \mathrm{v} 05 \mathrm{i} 05.003$

| Received: 30.03.2020 | Accepted: 06.04.2020 | Published: 17.05.2020

*Corresponding author: Marhari Halima

\section{Abstract}

Although the stimulating effect of thyroid hormones on energy metabolism has been known for about a century, the relationship between thyroid function, weight control, and obesity is unclear. Objective: Our work aims to bring a focus on the association between obesity and thyroid pathology. Methods: A descriptive and retrospective study of all obese patients who had consulted or been hospitalized in the Department of Endocrinology, Diabetology and Nutrition at University Hospital Center Hassan II in Fez, over a period of 2 years from January 2016 to December 2018. All patients with a BMI $\geq 30 \mathrm{~kg} / \mathrm{m}^{2}$ were included. The data were plotted on a table in the Excel 2010 program and analyzed using the SPSS 18 program. Results: 150 patients met our criteria, their mean age was $45.26+/-12.77$ years with a female predominance $($ sex-ratio $=1 / 25) .10 .66 \%$ of our patients had dysthyroidism; among them hypothyroidism was individualized in $56.25 \%$ of cases. In this category, the serum TSH concentrations were positively correlated with BMI $(p=0.011)$ and a significant weight loss was objectified after the start of hormonal treatment. While hyperthyroidism was present in $43.75 \%$ of our patients, $57.14 \%$ had morbid obesity and the response to weight gain after radical treatment (iratherapy or surgery) was minimal. Conclusion: Obese patients may develop thyroid dysfunction and even thyroid dysfunction may contribute to the gradual increase in body weight, resulting in overt obesity.

Keywords: BMI, TSH, subclinical hypothyroidism, overt hypothyroidism, subclinical hyperthyroidism, overt hyperthyroidism.

Copyright @ 2020: This is an open-access article distributed under the terms of the Creative Commons Attribution license which permits unrestricted use, distribution, and reproduction in any medium for non-commercial use (NonCommercial, or CC-BY-NC) provided the original author and source are credited.

\section{INTRODUCTION}

Obesity is a complex health disorder; increasing dramatically worldwide over the last few decades [1] and can be accompanied by many severe health complications [2].

Pathophysiologically, Obesity results from a positive energy balance, when dietary energy intake is greater than energy expenditure. This energy balance is regulated essentially by thyroid hormones.

The prevalence of dysthyroidism in obese patients is rare and a few studies investigated the association between thyroid function and body weight. However, in recent years this combination becomes more and more focused.

\section{OBJECTIVE}

The aim of our work is to study the possible association between thyroid statue and the body mass index (BMI) in a population of obese patients.

\section{PATIENT AND METHOD}

This is a descriptive retrospective study with data coming from the analysis of medical records of obese patients who had consulted or been hospitalized in the Department of Endocrinology, Diabetology and Nutrition at University Hospital Center Hassan II in Fez, over 2 years period from January 2016 to December 2018.

The study population consisted of any patient of both sexes, voluntary and having a BMI greater than or equal to $30 \mathrm{~kg} / \mathrm{m} 2$;

The analysis of the weight variations was done by the computation of BMI or the index of QUETELET, of the patients at the time of the discovery of the dysthyroidism and after getting euthyroidism.

According to obesity BMI criteria recommended by the World Health organization (WHO) [3], our population was divided into three groups:

- Class I with moderate obesity: BMI between 30.0$34.9 \mathrm{~kg} / \mathrm{m}^{2}$; 
- $\quad$ Class II with severe obesity: BMI between 35 -39.9 $\mathrm{kg} / \mathrm{m}^{2}$;

- Class III with morbid obesity: $\mathrm{BMI} \geq 40.0 \mathrm{~kg} / \mathrm{m}^{2}$

We have excluded all patients with a BMI less than $30 \mathrm{~kg} / \mathrm{m}^{2}$, medical records with missing data and patients having thyroid dysfunction prior to enrollment.

\section{A study sheet was used to exploit the following data}

General information and medical history: Age, sex, smoking, thyroid neoplasia, environmental factors, iodine intake.

Physical examination: anthropometric measurements (body weight, height, body mass index (BMI) and waist circumference), bioelectrical impedance analysis, clinical features of dysthyroid, cervical examination and general examination;

Biochemical parameters: TSH, fT3, fT4, AntiTPO AB / anti RTHS AB, cervical echography, assessment of obesity complications including metabolic balance, phosphocalcic balance, nutritional and vitamin balance, transthoracic ultrasound, abdominal ultrasound.

The data were plotted on a table in the Excel 2010 program and analyzed using the SPSS 18 program (Statistical Package for the Social Sciences); categorical variables were presented as numbers (percentages) and continuous variables were expressed as means.

\section{RESULTS}

\section{General population}

- We collected 150 patients with a mean age of $45.26+/-12.77$ years (age range 20 to 72 years), with a female predominance (sex-ratio $=1 / 25$ ).

- No cases of thyroid neoplasia or smoking has been reported,

- The mean serum TSH concentration was $2.03 \pm$ $2.71 \mu \mathrm{UI} / \mathrm{ml} ; 24.16 \%$ of patients had an impaired fasting glycemia (IFG) and 32\% had dyslipidemia;

Table-1: Baseline Characteristics of the Study Participants

\begin{tabular}{|c|c|c|c|c|}
\hline & \multicolumn{2}{|l|}{ No dysthyroidism } & \multirow{2}{*}{$\begin{array}{l}\text { hypothyroidism } \\
1 / 9\end{array}$} & \multirow{2}{*}{$\begin{array}{l}\text { Hyperthyroidism } \\
1 / 7\end{array}$} \\
\hline Sex ratio(F/M) & & $1 / 22$ & & \\
\hline \multirow{3}{*}{$\operatorname{BMI}\left(\mathrm{kg} / \mathrm{m}^{2}\right)$} & Grade I & $24.3 \%$ & $20 \%$ & $42.8 \%$ \\
\hline & Grade II & $21.3 \%$ & $20 \%$ & $15.01 \%$ \\
\hline & Grade III & $54.4 \%$ & $60 \%$ & $41.8 \%$ \\
\hline Waist $\operatorname{size}(\mathrm{cm})$ & & $118 ; 5 \pm 13.3$ & $130 \pm 10,2$ & $125+/-8.7$ \\
\hline $\begin{array}{l}\text { TSH serum levels } \\
(0,35-4,98 \mu \mathrm{IU} / \mathrm{ml})\end{array}$ & & $1.49 \pm 0.82$ & $11.9 \pm 3.05$ & $0.121+/-0.14$ \\
\hline \multirow{7}{*}{ Metabolic assessment } & IFG & $14.92 \%$ & $28.5 \%$ & $33.33 \%$ \\
\hline & $\begin{array}{l}\text { AST }(0 \text { - } 35 \text { UI/L): } \\
\text { ALT }(0 \text { - } 35 \text { UI/L): }\end{array}$ & $\begin{array}{l}18.86 \pm 7.10 \\
19.9 \pm 8.07\end{array}$ & $\begin{array}{l}16.57 \pm 0,97 \\
17.28 \pm 2.16\end{array}$ & $\begin{array}{l}21.66 \pm 8.8 \\
18.5 \pm 7.34\end{array}$ \\
\hline & $\mathrm{CT}(<2 \mathrm{~g} / \mathrm{l})$ & $1.80 \pm 0.33$ & $2.08 \pm 0.30$ & $1.73 \pm 0.3$ \\
\hline & LDLc & $1.15 \pm 0.31$ & $1.25 \pm 0.17$ & $0.97 \pm 0.2$ \\
\hline & $\operatorname{HDLc}(\mathrm{F}>0,5 \mathrm{~g} / \mathrm{H}>0,4)$ : & $0.41 \pm 0.12$ & $0,45 \pm 0.04$ & $0,50 \pm 0,06$ \\
\hline & TG $(<1,5 \mathrm{~g} / \mathrm{l})$ : & $1.38 \pm 0.55$ & $1,66 \pm 0.64$ & $1,20 \pm 0.40$ \\
\hline & $\begin{array}{l}\text { Uric acid } \\
(20-70 \mathrm{mg} / \mathrm{l}) \text { : }\end{array}$ & $56.06 \pm 14.4$ & $52.25 \pm 6.4$ & $52.33 \pm 9.9$ \\
\hline \multirow{10}{*}{$\begin{array}{l}\text { Nutritional and vitamin } \\
\text { assessment }\end{array}$} & $\begin{array}{l}\text { Hemoglobin } \\
(\mathrm{g} / \mathrm{dl}) \text { : }\end{array}$ & $13.13 \pm 1.26$ & $13.17 \pm 1.9$ & $14.2 \pm 0.48$ \\
\hline & $\begin{array}{l}\text { Serum iron } \\
(0.7-1.8 \mathrm{mg} / \mathrm{l})\end{array}$ & $064 \pm 0.40$ & $0.36 \pm 0.20$ & $0.57 \pm 0.27$ \\
\hline & $\begin{array}{l}\text { Serum Ferritin } \\
(18-300 \mathrm{ng} / \mathrm{mL})\end{array}$ & $62.95 \pm 40,74$ & $33,42 \pm 18,38$ & $67.25 \pm 15.87$ \\
\hline & $\begin{array}{l}\text { Serum calcium } \\
(88-105 \mathrm{mg} / \mathrm{l}) \text { : }\end{array}$ & $93.95 \pm 4.60$ & $91.37 \pm 2.50$ & $95.25 \pm 5.31$ \\
\hline & $\begin{array}{l}\text { Phosphatemia } \\
(25-45 \mathrm{mg} / \mathrm{l}) \text { : }\end{array}$ & $34.60 \pm 76.68$ & $35 \pm 0.10$ & $36 \pm 0.18$ \\
\hline & $\begin{array}{l}\text { Vitamin D } \\
(>30 \mathrm{ng} / \mathrm{mll}) \text { : }\end{array}$ & $14.75 \pm 9.20$ & $15.7 \pm 5.4$ & $18.42 \pm 15.36$ \\
\hline & $\begin{array}{l}\text { Vitamin A } \\
(100-500 \mu \mathrm{g} / \mathrm{l})\end{array}$ & $167.16 \pm 25$ & $165.17 \pm 27$ & $160.15 \pm 23$ \\
\hline & $\begin{array}{l}\text { Vitamin B1 } \\
(15-45 \mathrm{nmol} / \mathrm{L})\end{array}$ & $113.6 \pm 44,44$ & $113.6 \pm 34,03$ & $103.6 \pm 43.44$ \\
\hline & $\begin{array}{l}\text { Vitamin B9 } \\
(4-22 \mathrm{nmol} / \mathrm{L})\end{array}$ & $11.45 \pm 7.22$ & $10.45 \pm 9.29$ & $14.45 \pm 5.22$ \\
\hline & $\begin{array}{l}\text { Vitamin B12 } \\
(150-750 \mathrm{pmol} / \mathrm{L})\end{array}$ & $268.60 \pm 55.12$ & $283.07 \pm 50.12$ & $245.67 \pm 59.12$ \\
\hline
\end{tabular}




\section{Population with hypothyroidism}

- $10.66 \%$ of our population had dysthyroidism with female predominance $($ sex ratio $=0.06$ )

- Among those cases, 56.25\% had hypothyroidism; the mean BMI was $42.5 \pm 4,07 \mathrm{~kg} / \mathrm{m}^{2}$ and the average waist circumference was $130 \pm 10 \mathrm{~cm}$,

- The bioelectrical impedance analysis noted a weight gain at the expense of the body fat which the average was $41.9 \pm 2.23 \mathrm{~kg}$.

- $28.5 \%$ had an IFG and $22.2 \%$ had dyslipidemia, the mean serum TSH concentration was $11.9 \pm$ $3.05 \mu \mathrm{UI} / \mathrm{ml}$, we noted a significant relationship between serum TSH levels and BMI $(p=0.011)$, without correlation with age or sex.
- $25 \%$ of our patients had subclinical hypothyroidism and $75 \%$ had overt hypothyroidism; the causal etiology was Hashimoto's thyroiditis in $44.4 \%$ of cases, the origin from a deficiency zone of iodine with goiter in $33.3 \%$ of cases.

- The impact of thyroid hormone therapy on weight loss, in our patients with hypothyroidism, was significant with a mean weight loss of $4.8 \mathrm{~kg}$ at 3 months of treatment and $6.4 \mathrm{~kg}$ at 6 months (Figure 1), (Table 2); also in the bioelectrical impedance analysis we founded a significant decrease in the fat mass, while the fat-free mass remained in the norms.

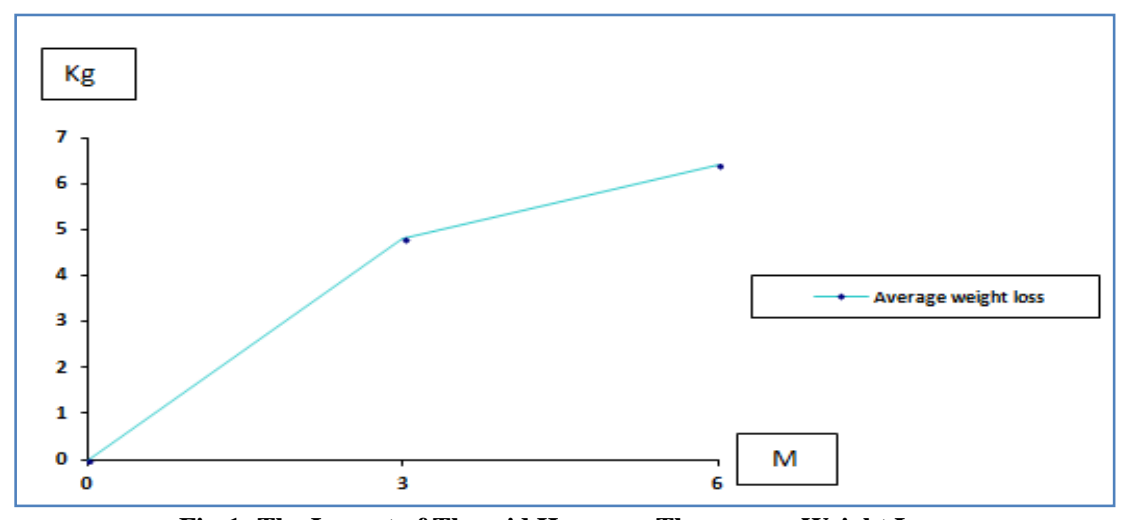

Fig-1: The Impact of Thyroid Hormone Therapy on Weight Loss

\section{Population with hyperthyroidism}

- Hyperthyroidism was individualized in $43.75 \%$ of cases, the average of BMI was $35.8 \pm 8.70 \mathrm{~kg} / \mathrm{m}^{2}$ and the average of waist circumference was $118.28 \pm 23.09 \mathrm{~cm}$;

- The bioelectrical analysis noted a weight loss at the expense of the fat-free mass (FFM);

- $\quad$ The average of TSH was $0.141 \pm 0.147 ; 33.33 \%$ had an IFG and no cases of dyslipidemia were recorded,
- $43 \%$ of our patients had subclinical hyperthyroidism and $57 \%$ had overt hyperthyroidism; the etiology was a multinodular goiter in $71.42 \%$ and a Grave's disease in $28.5 \%$ of cases.

- After radical treatment of toxic goiter, a modest weight loss was noted with an average of $0.5 \mathrm{~kg}$ at 3 months and $1.7 \mathrm{~kg}$ after 6 months (Figure 2), (Table 2).

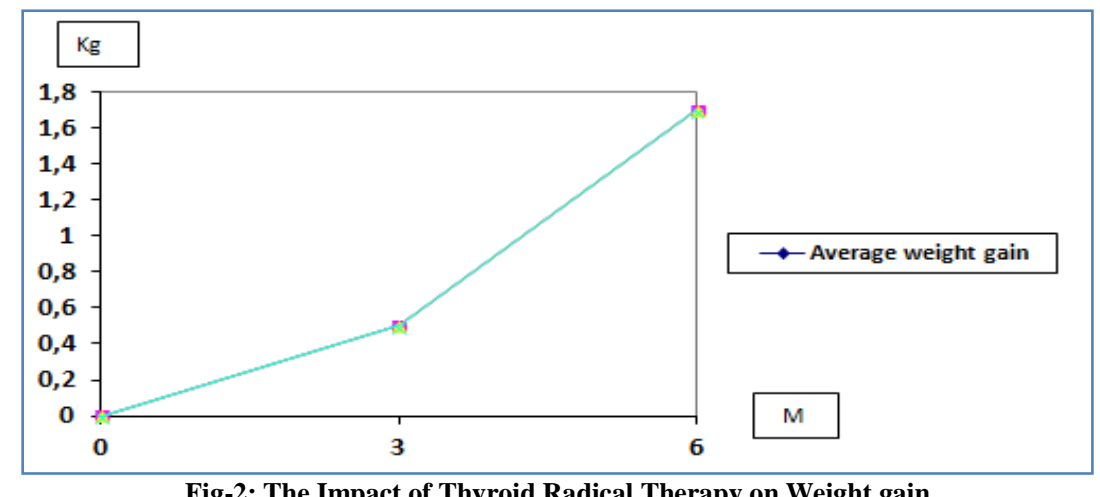

Fig-2: The Impact of Thyroid Radical Therapy on Weight gain

Table-2: Comparison of weight loss between general population and patients with thyroid dysfunction

\begin{tabular}{|l|l|l|l|}
\hline & Euthyroidism & Hypothyroidism & Hyperthyroidism \\
\hline 03 months & $-5.2 \pm 5 \mathrm{Kg}$ & $-4.8 \pm 2 \mathrm{Kg}$ & $+0.5 \pm 0.5 \mathrm{Kg}$ \\
\hline 06 months & $-7.7 \pm 7 \mathrm{Kg}$ & $-6.4 \pm 4 \mathrm{Kg}$ & $+1.7 \pm 0.3 \mathrm{Kg}$ \\
\hline
\end{tabular}




\section{DISCUSSION}

A rising prevalence of obesity is reported throughout the world and remains an important public health problem $[4,5]$. At the same time, it is associated with endocrine system disorder especially dysthyroidism; this relationship can be explained by the regulatory role played by fT3 on the energy metabolism and thermogenesis like the metabolism of glucose, lipids and oxidation of fatty acids[6].

\section{Two contrasting hypotheses had been proposed to explain this relationship:}

- Obese patients are more likely to develop autoimmune hypothyroidism, and even a mild thyroid insufficiency may contribute to the gradual increase in body weight.

- Obese patients often have a high TSH level, which is not indicative of hypothyroidism [7].
Neither hypothesis alone is enough to explain this complex relationship; however the current available data points to an implication of these two mechanisms. Furthermore, another hypothesis linked the association between serum TSH and body weight to an elevation of leptin values $[8,9]$, this association was not treated in our study because of the unavailability of the dosage of the leptin in the laboratory of our hospital center.

Evidence suggests that slight variations in thyroid function may be associated with obesity; although the prevalence of this association remains variable in different research studies (Table 3); that can be justified by the difference in race, degree of obesity, environmental factors and lifestyle of participants as well as the sample size.

Table-3: Comparing Prevalence Estimates of Dysthyroidism

\begin{tabular}{|l|l|l|l|l|l|l|l|}
\hline & $\begin{array}{l}\text { Our } \\
\text { Study }\end{array}$ & $\begin{array}{l}\text { Reinehr. T } \\
\text { et al. } \\
{[\mathbf{1 0} \mathbf{2 0 0 8})}\end{array}$ & $\begin{array}{l}\text { Elizabeth. } \\
\mathbf{N} \text { et al. } \text { [11] } \\
(\mathbf{2 0 1 2})\end{array}$ & $\begin{array}{l}\text { Fierabracci. } \\
\text { P et al. } \text { [12] } \\
(\mathbf{2 0 1 1})\end{array}$ & $\begin{array}{l}\text { Marina. A } \\
\text { et al. } \\
{[\mathbf{1 3}](\mathbf{2 0 0 6})}\end{array}$ & $\begin{array}{l}\text { Nicoleta. R } \\
\text { and } \text { et al. } \\
{[\mathbf{1 4}](\mathbf{2 0 1 7})}\end{array}$ & $\begin{array}{l}\text { Biswas. K } \\
\text { et al. } \\
{[\mathbf{1 5}](\mathbf{2 0 1 7})}\end{array}$ \\
\hline hypothyroidism & $6 \%$ & $23 \%$ & $4,6 \%$ & $18.1 \%$ & $11.8 \%$ & $14.6 \%$ & $37 \%$ \\
\hline hyperthyroidism & $4,6 \%$ & $20 \%$ & $1,3 \%$ & $0 \%$ & $0.7 \%$ & $1,2 \%$ & $34.25 \%$ \\
\hline
\end{tabular}

Our study assesses the prevalence of this association; the most common endocrine thyroid disease was hypothyroidism (6\%), followed by hyperthyroidism $(4.6 \%)$.

In patients with hypothyroidism, we noted a significant relationship between serum TSH levels and BMI $(p=0.011), 25 \%$ had subclinical hypothyroidism and $75 \%$ had overt hypothyroidism; the most common etiology was Hashimoto's thyroiditis in $44.4 \%$, followed by iodine deficiency with goiter in $33.3 \%$ of cases.

Some studies of the association between anthropometric measurements and serum TSH levels, reported conflicting results; Nevertheless, a metaanalysis of 29 studies showed a positive association between serum TSH concentration and BMI or body weight $[16,17]$ which confirms the results of our study. This association could be mediated by a direct action of $\mathrm{TSH}$, in the stimulation of the differentiation of preadipocytes, thus inducing adipogenesis $[18,19]$.

The prevalence of subclinical hypothyroidism was similar with that reported in the results of Moalla et al. [20] in a retrospective study about 57 patients obese; and those of Marina et al. [x] in her study about 144 morbidly obese patients.

The most common etiology in our study was Hashimoto's thyroiditis, which suggests a causal relationship between onset of dysthyroidism in obese patients and autoimmunity; only some studies had analyzed this subject [21, 22]. Rotondi [23] has conducted a study that compared the prevalence of subclinical hypothyroidism in morbidly obese patients and normal weight patients, by analyzing serum antiTPO AB levels; the results showed that thyroid autoimmunity was not a major cause of the high rate of subclinical hypothyroidism in morbidly obese patients, which leaves us doubt about this relationship. However, morbid obesity is associated with an increasement of TSH level that can be explained by the impaired control of free thyroid hormones and by the elevation of fT3 as an adaptive phenomenon to increase energy expenditure.

Therapeutically; in the literature review, the effects of hormone therapy on body weight and body composition is contradictory [23, 24]. In our study, a significant weight loss, at the expense of the fat mass, was objectified ( $4.8 \mathrm{~kg}$ in 3 months which doubled after 06 months of treatment).

Inversely to hyporthyroidism; a few studies had been conducted in obese patients with hyperthyroidism (overt and subclinical) and a low prevalence had been reported. The mechanism of this association is poorly understood; however the effects of treatment on body weight gain had been approved by some authors and disapproved by others. In our findings, hyperthyroidism was noted in $4.6 \%$ of cases and the common etiology was multinodular goiter, a non-significant weight gain after treatment was noted, at the expense of lean body mass. Conversely to our results; other studies [25] found a significant weight gain, such as the results of Hoogwerf's study [26] about the body weight regulation after treatment of 87 
patients in 96 months, which showed a recovery of $100 \%$ of the lost weight after one year of treatment and of $102.5 \%$ after 08 years.

This discrepancy between our results and those of other authors may be explained by the differences in dietary habits, the sample size, and the short duration of follow-up and to the involvement of other factors such as the transition to hypothyroidism before finding the appropriate thyroxine substitutive dose and the change of the food mode.

\section{CONCLUSION}

The association between BMI and dysthyroidism remains unclear; however clinicians must be particularly attentive to the possibility of this association.

Another hypothesis supposes that the association between TSH serum and body weight could be due to an elevation of leptin, hence the interest of carrying out other supplementary research reversing or confirming this hypothesis.

\section{Conflict of interest}

The authors declared no conflict of interest

\section{REFERENCES}

1. Basdevant, A. (2000, December). Obesity: epidemiology and public health. In Annales d'endocrinologie (Vol. 61, pp. 6-11).

2. Kopelman, P. G. (2000). Obesity as a medical problem. Nature, 404(6778), 635-643.

3. World Health Organization. (2000). Obesity: preventing and managing the global epidemic (No. 894). World Health Organization.

4. Ng, M., Fleming, T., Robinson, M., Thomson, B., Graetz, N., Margono, C., ... \& Abraham, J. P. (2014). Global, regional, and national prevalence of overweight and obesity in children and adults during 1980-2013: a systematic analysis for the Global Burden of Disease Study 2013. The lancet, 384(9945), 766-781.

5. Kent, S., Green, J., Reeves, G., Beral, V., Gray, A., Jebb, S. A., ... \& Alison, R. (2017). Hospital costs in relation to body-mass index in 1.1 million women in England: a prospective cohort study. The Lancet Public Health, 2(5), e214-e222.

6. Ritz, P., Dumas, J. F., Salle, A., Simard, G., Malthiery, Y., \& Rohmer, V. (2002). Hormones thyroïdiennes et obésité. In Annales d'endocrinologie (Vol. 63, No. 2, pp. 135-139). Masson.

7. Rotondi, M., Magri, F., \& Chiovato, L. (2011). Thyroid and obesity: not a one-way interaction. The Journal of Clinical Endocrinology \& Metabolism, 96(2), 344-346.

8. Sahar, H. (2018). The influence of thyroid hormones on leptin and resistin levels in hyperthyroid female patients. International Journal of Medical Research \& Health Sciences, 7(1), 4047.

9. Katsuhiro, T., Mai, S., Shiori, S., Ryohei, O., Wataru, S., \& Yusuke, O.(2018). Expression of Leptin and Leptin Receptor Messenger Ribonucleic Acids in Thyroid Carcinoma. Annals Thyroid Res, 4(1): 126-129.

10. Reinehr, T., Isa, A., De Sousa, G., Dieffenbach, R., \& Andler, W. (2008). Thyroid hormones and their relation to weight status. Hormone Research in Paediatrics, 70(1), 51-57.

11. Pearce, E. N. (2012). Thyroid hormone and obesity. Current Opinion in Endocrinology, Diabetes and Obesity, 19(5), 408-413.

12. Fierabracci, P., Pinchera, A., Martinelli, S., Scartabelli, G., Salvetti, G., Giannetti, M., ... \& Rago, T. (2011). Prevalence of endocrine diseases in morbidly obese patients scheduled for bariatric surgery: beyond diabetes. Obesity surgery, 21(1), 54-60.

13. Michalaki, M. A., Vagenakis, A. G., Leonardou, A. S., Argentou, M. N., Habeos, I. G., Makri, M. G., .. \& Kyriazopoulou, V. E. (2006). Thyroid function in humans with morbid obesity. Thyroid, 16(1), 73-78.

14. Nicoleta, R., Nicoleta, L., Cosmina, L.B., Smaranda, M., Daniela, M., Ana, V.(2017). Insulin resistance and thyroid pathology. Arch Endocrinol Metab, 61:6.

15. Biswas, K., Nandi, T., \& Satter, T. B. (2017). Investigation of thyroid hormone status among obese women of the endocrine outpatient department in a tertiary level hospital. Pharm Pharmacol Int J, 5(4), 147-149.

16. Choi, S. H., Lee, Y. J., Park, Y. J., Kim, K. W., Lee, E. J., Lim, S., ... \& Cho, B. Y. (2008). Retinol binding protein-4 elevation is associated with serum thyroid-stimulating hormone level independently of obesity in elderly subjects with normal glucose tolerance. The Journal of Clinical Endocrinology \& Metabolism, 93(6), 2313-2318.

17. Răcătăianu, N., Leach, N., Bondor, C. I., Mârza, S., Moga, D., Valea, A., \& Ghervan, C. (2017). Thyroid disorders in obese patients. Does insulin resistance make a difference?.Archives of endocrinology and metabolism, 61(6), 575-583.

18. Sorisky, A., Bell, A., \& Gagnon, A. (2000). TSH receptor in adipose cells. Hormone and Metabolic Research, 32(11/12), 468-474.

19. Mishra, A., Zhu, X. G., Ge, K., \& Cheng, S. Y. (2010). Adipogenesis is differentially impaired by thyroid hormone receptor mutant isoforms. Journal of molecular endocrinology, 44(4), 247.

20. Moalla, H., Cheikh, M. B., Mahjoub, F., Souissi, N., Messaoui, I., Boumefeteh, S., ... \& Jamoussi, H. (2018, September). Faut-il dépister systématiquement une hypothyroïdie chez les sujets obèses?. In Annales d'Endocrinologie (Vol. 79, No. 4, p. 357). Elsevier Masson. 
21. Tamer, G., Mert, M., Tamer, I., Mesci, B., Kılıc, D., \& Arık, S. (2011). Effects of thyroid autoimmunity on abdominal obesity and hyperlipidaemia. Endokrynologia polska,62(5), 421-428.

22. Rotondi, M., Leporati, P., La Manna, A., Pirali, B., Mondello, T., Fonte, R., ... \& Chiovato, L. (2009). Raised serum TSH levels in patients with morbid obesity: is it enough to diagnose subclinical hypothyroidism?. European Journal of Endocrinology, 160(3), 403.

23. Ozdemir, S., Ozis, E. S., Gulpinar, K., Aydin, T. H., Suzen, B., \& Korkmaz, A. (2010). The effects of levothyroxine substitution on body composition and body mass after total thyroidectomy for benign nodular goiter. Endocrine regulations, 44(4), $147-$ 153.

24. Ambrosi, B., Masserini, B., Iorio, L., Delnevo, A., Malavazos, A. E., Morricone, L., ... \& Orsi, E. (2010). Relationship of thyroid function with body mass index and insulin-resistance in euthyroid obese subjects. Journal of endocrinological investigation, 33(9), 640-643.

25. Pears, J., Jung, R. T., \& Gunn, A. (1990). Longterm weight changes in treated hyperthyroid and hypothyroid patients. Scottish medical journal, 35(6), 180-182.

26. Hoogwerf, B. J., \& Nuttall, F. Q. (1984). Longterm weight regulation in treated hyperthyroid and hypothyroid subjects. The American journal of medicine, 76(6), 963-970. 